\title{
КРИЗИС ОРГАНИЗАЦИИ КАК ИСТОЧНИК СТРЕССА ДЛЯ ПЕРСОНАЛА
}

Гнедых Ю.И. Научный руководитель: к.псх.н., доцент Макаревская Ю.Э.

Исходя из литературных источников, рассматривающих проблемы организации и управления, общепризнанным является тот факт, что кризисная ситуация серьезно угрожает функционированию всей системы и проистекает из внешних условий (Кирсанов А.И, 2000; Александров Г.А., 2002; Родионова Н.В., 2002; Фомин Я.А., 2003; Бартоли А., Эрмед Ф., 1986 и др.) Если меры по выходу из кризиса оказываются недостаточными для устранения проблемы, кризисная ситуация продолжается.

Для организаций кризис - это дезинтеграция, которая затрагивает систему не только как единое целое, но также оказывает фатальное воздействие на ее первоосновы, ее суть. Таким образом, кризис - это «разрушитель системы», затрагивающий эмоциональный, познавательный и поведенческий аспекты, которые Херманн определил, как непредвиденную угрозу выживания системы.

То есть любой кризис организации, даже самый предсказуемый и мягкий это напряжённая ситуация для коллектива.

То есть кризисы, безусловно, являются фактором усложнения условий деятельности людей в рамках конкретной организации.

Напряженная ситуация кризиса (объективно усложнившиеся условия и процесс деятельности) предъявляет особые требования к состояниям, установкам, способам действий включенных в нее людей.

Становится ли стрессом ситуация кризиса организации для персонала?

Да, если кризис кроме внешних давлений еще и воспринимается коллективом как трудный, сложный, опасный период, то ситуация в организации становится все более напряжённой.

Рассмотрим, какие причины организационного стресса могут быть инициированы внешним экономическим кризисом:

- страх потерять работу (волны сокращений);

- страх быть обойденным другими (высокая конкуренция на рынке труда);

- нарушение чувства комфорта и безопасности труда (экономия на модернизации оборудования);

- длительная работа без отдыха, переутомление (работать приходится больше);

- дефицит времени для завершения плановых заданий (связано с быстротечностью задач) и др.

То есть, находясь на рабочем месте, сотрудник организации, которая находится в состоянии кризиса, практически все время находится в состоянии напряжения. И, учитывая накопительный характер стрессов, правомерно предположить, что в случае длительного стресса проблемы индивида будут нарастать. В соответствии с теорией $Г$. Селье истощенный стрессами человеческий организм постепенно утрачивает способность к восстановлению. Противостояние стрессу ослабляет людей как физически, так и психологически. 
Такое состояние называется истощением сил (дистрессом), когда эмоционально опустошенные работники отдаляются от работы, ощущают беспомощность.

Работники, силы которых на исходе, склонны к постоянным жалобам, связывают свои ошибки с действиями других людей, раздражительны. Отчуждение, которое они испытывают, побуждает их задуматься об уходе с работы, к поиску возможностей получения новой профессии. Помимо увеличения текучести кадров истощение сил приводит к повышению показателей невыходов на работу и снижению производительности труда.

Естественно, это не в интересах организаций.

Вероятно, большинство организаций обладает потенциалом, позволяющим справиться с кризисной ситуацией, и процессы, порождающие кризис, в действительности идентичны процессам, порождающим успех. Кризисы часто служат поводом для реорганизации, и достоверно известно, что некоторые компании используют ее как главенствующую стратегию. В перспективе данного исследования мы будем рассматривать особый тип организационного кризиса, который обоснованно и предусмотрительно был внедрен руководящим персоналом как «инициированный кризис» («autogenic crisis»). Согласно этому типу внедряемого в организациях кризиса, руководители сознательно инициируют организационные перемены путем уведомления членов группы о грядущих радикальных внешних переменах, которые могут поставить под угрозу корпоративное индивидуальное благополучие. Реакция на данный тип кризиса предполагает активизацию информационного обмена и децентрализацию контролирующих процессов; результатом кризиса является большая организационная гибкость и стабильная жизнеспособность. Мы полагаем, что осознание специфики конструктивного кризиса помогает объяснить, каким образом организации в условиях кризиса могут осуществить как экстренную адаптацию, в основе которой лежит мобильность и конструктивность принимаемых мер, так и долгосрочные изменения, затрагивающие обновление и совершенствование всей структуры.

Кроме того, в ситуации кризиса, мы рекомендуем организациям выявлять сотрудников, у которых проявляются симптомы стресса и помочь им научиться справляться со стрессовыми ситуациями в процессе труда.

В совокупности управленческие поддерживающие меры работают как антикризисные и в перспективе данного исследования: разработка и реализация методики повышения стрессоустойчивости персонала.

\section{Литература:}

1. Александров Г.А. "Антикризисное управление: теория, практика, инфраструктура". - М.: "Бек", 2002. - 544 с. Александров Г.А. "Антикризисное управление: теория, практика, инфраструктура". - М.: "Бек", 2002.

2. Бартоли А., Эрмед Ф. "Управление предприятием в условиях перемен. Стратегический подход к преобразованиям". - Париж, 1986.

3. Попов Р.А. "Антикризисное управление". - М.: "Высшая школа", 2003. 
4. Родионова Н.В. "Антикризисный менеджмент". - М.: "ЮНИТИ", 2002.

5. Фомин Я.А. "Диагностика кризисного состояния предприятия". - М.: "ЮНИТИ", 2003.

\section{ПРОБЛЕМА ВЛИЯНИЯ СТИЛЯ РУКОВОДСТВА НА ПОДЧИНЕННЫХ \\ Григорьев М.В., Макаревская Ю.Э.}

Согласно наиболее распространенной в управленческой культуре классификации, выделяют три основных стиля управления: авторитарный, демократический и либеральный [4].

При авторитарном стиле управления максимум полномочий концентрируется в руках одного человека, который лично задает вектор деятельности своих подчиненных, сам решает основные производственные вопросы и использует традиционные (основанные на принуждении) инструменты влияния. Это не самый благоприятный с точки зрения психологического климата стиль управления, но в некоторых ситуациях он оправдан, например:

- в условиях кризисных или чрезвычайных ситуаций;

- на первых этапах формирования нового коллектива;

- в ситуациях, требующих быстрой мобилизации ресурсов;

- в организациях с четкой иерархической структурой (например, в армии).

При демократическом стиле управления власть децентрализована: руководитель периодически советуется со своими подчиненными, обращается за консультациями к сторонним специалистам и только после этого принимает важные решения. Подчиненный получает достаточно информации для понимания перспектив развития, инициатива на местах приветствуется и стимулируется.

Часть управленческих полномочий делегируется подчиненным, в структуре организации присутствуют элементы коллективного самоуправления. Вместо принуждения используются другие инструменты власти - личный пример, поощрение и т. д.[8]

Это наиболее благоприятный стиль управления, но его реализация возможна лишь при условии высокого авторитета руководителя и наличии у него развитых организаторских и коммуникативных способностей.

Названный выше стили имеют как достоинства, так и недостатки которые хорошо представлены в литературе.

Либеральный стиль управления подчиненными еще называют анархическим или попустительским. При такой манере руководства сам руководитель не может управлять ситуацией в группе подчиненных, так как каждый подчиненный сам по себе. Руководитель в данном случае номинальная фигура. Данный стиль управления исследователи рассматривают как недопустимый и лишенный достоинств. Поэтому дальнейший анализ либерального стиля управления не имеет смысла [3]. 